
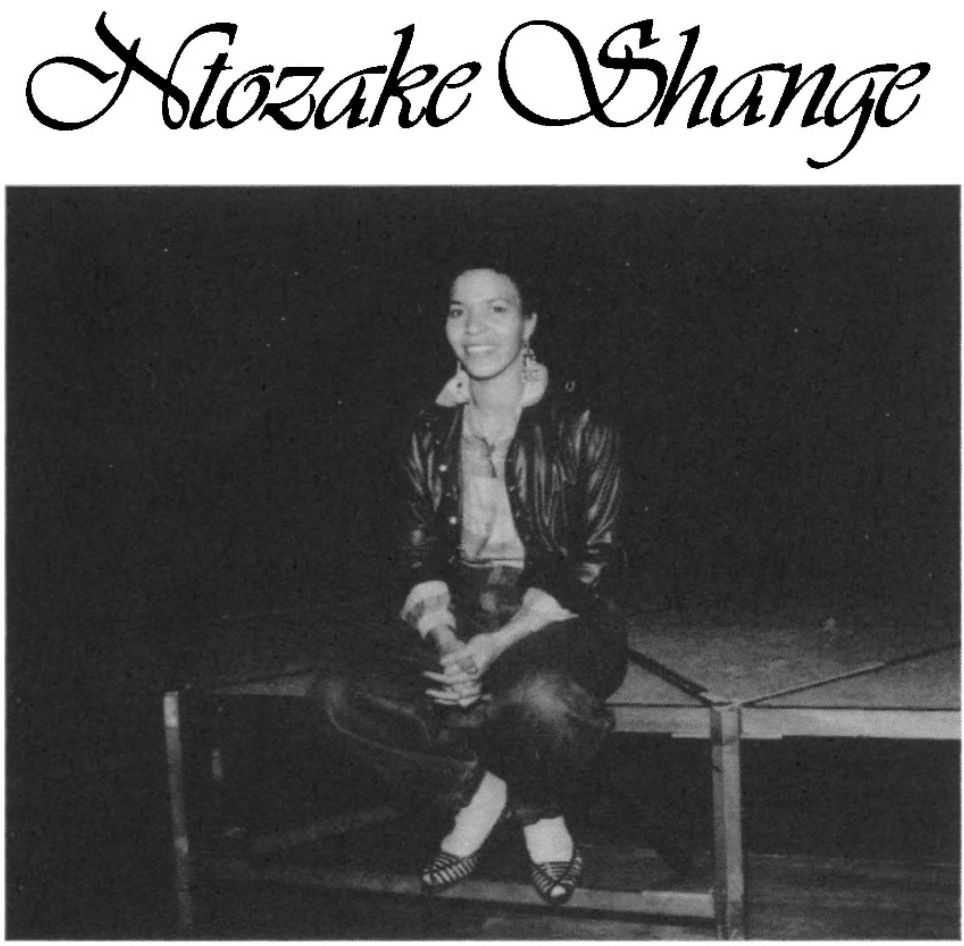

Sassafrass, Cypress and Indigo Ntozake Shange Methuen $1983 £ 2.95$ ISBN 0413519708

Sassafrass, Cypress and Indigo is the story of three Black girls, three sisters, and their mama from Charleston, South Carolina. The story is set in the present and describes a year of their lives. The two elder sisters are away from home: Sassafrass is in New England living as a poet and a weaver, Cypress is studying dance in New York and Indigo is still at home. At certain times they meet up at home but the story does focus on their lives miles apart.

They are an artistic and creative family with a history of spinning and weaving going back to slavery times. In many ways they are extraordinary in that there is a possibility for their artistic talents to be explored and trained. This possibility is largely due to their mother's scrimping and saving. Their mama is a strong and resourceful 
woman. She stays at home with Indigo. She loves her daughters, she wants to change their lives:

Make it so they wouldn't have to do what she did. Listen to every syllable come out that white woman's mouth. It wasn't really distasteful to her. She liked her life. She liked making cloth; the touch, the rhythm of it, colors. What she wanted for her girls was more than that. She wanted happiness, however they could get it. Whatever it was. Whoever brought it!

Their stories are valid and affirmative in that they discover certain levels of happiness in a variety of ways. Sassafrass decides to have a baby and return to mama. Cypress wins public acclaim as a dancer and ends up marrying. Indigo becomes involved in music and folklore. There is also a validation in that the positive possibility of Black women experiencing love and sexual relationships with other Black women is opened up. This is clearly seen in Cypress' relationship with Idrina. Cypress writes:

$$
\begin{gathered}
\text { Journal entry } 151 \\
\text { yesterday my bosoms } \\
\text { kept fallin out } \\
\text { my shirts } \\
\text { move easily when i turn } \\
\text { the right nipple wiggles } \\
\text { but/ } \\
\text { idrina says } \\
\text { 'what's a lil titty 'mong friends?' }
\end{gathered}
$$

In a way it is a shame that in spite of this exploration the two elder sisters retain the heterosexual status quo. But perhaps that is a more 'realistic' approach to Black women who may be women identified but who are unable, for a multitude of reasons, to 'come out' in the Black community. Ntozake Shange's use of language is immediate and evocative. She does not only use it to tell a story, a character's idiosyncracies and development in a traditional fictional way, but she uses language like poetry to get the story over:

When she (Sassafrass) moved, she went over to her looms... makin cloth, bein a woman and longin

to be of the earth

a rooted blues

some ripe berries

happenin inside

spirits

walkin in a dirt road

She also juxtaposes different styles. There is a fictional style and a poetical style. There is a style comparing the America into which the sisters move and the Black African/weaving roots their mother upholds. There is a style telling of an individual's favourite recipes and the times when they cook this food and also Mama's letters to her three girls giving advice and love.

Being a Black woman in Britain I think there are some things I could identify with in the story - racism, an overwhelming desire to fulfill ourselves against all odds and homophobia. I did find the American language and style hard to follow. I don't have the black and white American culture ready at hand. But I did enjoy reading the book and could not put it down until the end.

\section{Sona Osman}

